\title{
BuILDing WATER SENSITIVE URBAN DESIGN: MODELLING OF GREEN ROOF
}

\author{
K.W. Ling ${ }^{1}$ and D.Y.S. Mah ${ }^{2}$ \\ ${ }_{1,2}$ Department of Civil Engineering, Faculty of Engineering, Universiti Malaysia Sarawak \\ Date received: 02/07/2015, Date accepted: 19/08/2015 \\ Corresponding author's email: ysmah@unimas.my
}

\begin{abstract}
This project evaluates green roofs as a stormwater management tool. The goal of the project is to develop a computer aided stormwater model incorporating green roof, and evaluate its effectiveness. Specifically, the influence of media type, media depth, duration of rainfall event and average reoccurrence interval are investigated in design rainfall. The finalised model is then validated based on observed rainfall for the months of January and February of 2014. Results indicate that the green roofs are capable of removing $73.5 \%$ and $86.9 \%$ of the monthly rainfall volumes for January and February 2014 , respectively, from a roof through retention. Water retention by green roofs effectively increases the time to reach the peak runoff, and slows the peak flows for a watershed. There are seasonal considerations as more runoff is generated during the month of January (northeast monsoon season) compared with the month of February (normal weather). Green roof is also effective in retaining $100 \%$ of several storms of less than $10 \mathrm{~mm}$. The results demonstrate that the proposed extensive green roof for the study area functions as an excellent bio-retention system for stormwater control. The results of this research are in tandem with those of other researches performed throughout the world on hydrologic characteristics of green roof.
\end{abstract}

Keywords: Stormwater management, Green roof, Growing media, Bio-retention system, Peak flow

\subsection{INTRODUCTION}

For decades, it has been observed that urbanisation increases the response of stormwater runoff to precipitation due to greater stormwater peaks generated by impervious surfaces [1]. The larger the area of impervious surfaces within a watershed, the more the natural ground cover is lost due to physical developments. Urbanisation processes cause the majority of rainfall to become runoff and infiltration is less than one-third of what it was prior to the developments. As a result, the increasing volume of stormwater runoff poses a major problem to the public and its ramifications to the environment and daily living escalate over the years.

Buildings have occupied the urban surfaces for a long time. Only recently, the idea of reclaiming the buildings' roof for greenery was introduced to compensate for the lost greenery in the concrete jungle. In its original concept, green roof is meant to counter the problem of urban heat island effect. In this study, green roof is used as a bio-retention system in an attempt to trap stormwater. It is designed to reduce the surface runoff and slow down the process of stormwater discharge into the drainage. In this regard, the EPA Storm Water Management Model (SWMM) version 5.1 is used for a single event of runoff quantity over green roof for the mentioned investigation.

Green roof is a type of bio-retention system which gains popularity among the owners of urban properties and the trend is spreading throughout the world. A green roof or living roof is the roof of a building that is partially or completely covered with vegetation; this is done by way of a growing medium laid over a waterproofing membrane on top of the roof. The system may also include additional layers such as a root barrier and drainage layer and irrigation network [2]. A Green roof serves several purposes for a building, such as absorbing rainwater, providing insulation and creating a habitat for wildlife. It also increases benevolence and decreases stress of the people around the roof by providing a more aesthetically pleasing landscape. In addition, it helps to lower urban air temperatures and mitigate the heat island effect [3]. There are two types of green roofs. The first is the intensive roof, which is thicker, with a minimum depth of $12.8 \mathrm{~cm}$, and can support a wider variety of plants but is heavier and 
requires more maintenance. The second is the extensive roof, which is shallow, ranging in depths from 2 to $12.7 \mathrm{~cm}$; it is lighter than the former, and requires minimal maintenance [4].

The components are generally the same for the extensive, semi-intensive and intensive green roofs, differing only in depths and project-specific design applications. Figure 1 shows the components of a green roof, which include growing medium, plants, filter sheet, drainage layer, protective layer, insulation and waterproofing materials. Green roof vegetation performs the similar function as that of a 'cool' roof by reflecting solar energy to the atmosphere. Planting medium depth and composition must be appropriate for the selected vegetation [5]. The growing medium used varies considerably in accordance with few factors, such as the type of plants and the proposed method of irrigation [6]. The filter layer is to prevent fine soil particles from washing into the drainage layer, which may cause clogging or reduce the drainage capacity [7]. The insulation layer is used to prevent water stored in the green roof system from extracting the heat in the winter or cooling the air in the summer. The waterproof membrane needs to have many properties in addition to its capacity to keep water from penetrating the building.

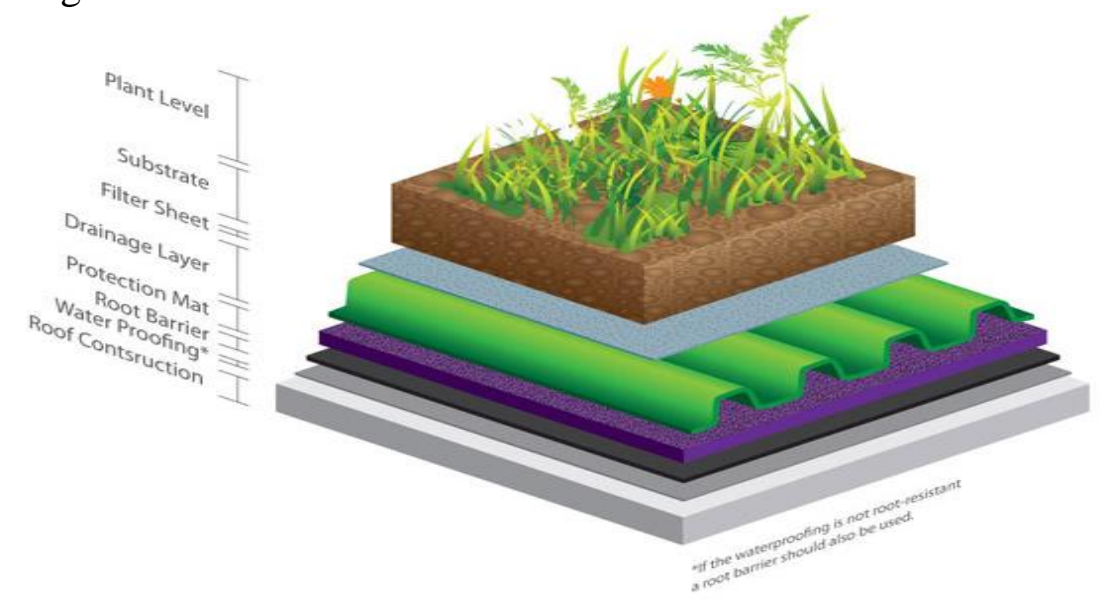

Figure 1. Green Roof Components (http://www.greenroofguide.co.uk/design/)

With the increase in number of green roof systems installed in a wide range of private and public properties, the benefits derived will be more apparent. The first main benefit is to reduce stormwater runoff. Green roofs can store significant amounts of water in their growing media. This water evaporates from the soil or is transpired by the plants on the roof [8]. These water-elimination processes reduce the runoff entering the drainage systems and waterways. Besides, green roofs can also reduce the energy consumption of buildings due to additional insulation provided by the growing media. The presence of plants and growing media reduces the amount of solar radiation reaching the roof's surface and decreases the temperature of roof surfaces [8]. Evaporative cooling from water retained in the growing media reduces roof surface temperatures.

Researchers from North Carolina had conducted research investigating the effectiveness of green roofs as a bio-retention system. Overall, each green roof retained $64 \%$ of the total precipitation recorded, and each green roof reduced the average peak flows by more than $75 \%$. Not only did the green roofs retain a significant proportion of the rainfall onto the roofs and significantly reduce the peak outflow rates from the rooftops, each green roof also substantially delayed the commencement of outflow. In many cases, the green roof outflow began after several hours of continued rainfall [9].

\subsection{METHODOLOGY}

This project utilises 3-storey shophouses in Central City, Kota Samarahan (Figure 2) with an area of $139.08 \mathrm{~m}^{2}$ per unit. In this project, green roofs are modelled to function as a bio-retention system. There are three critical factors to be taken into consideration in such modelling, namely types of soil, thickness 
of soil and anticipation of hydrologic events. SWMM 5.1 is used to study the above criteria in order to achieve an optimum reduction of surface runoff. The simulation results of the stormwater model incorporated with green roofs using design rainfall and observed rainfall are analysed. An analysis of the variables of green roof that may have effect on rainfall-runoff volume is carried out. There are four scenarios to be investigated based on design rainfall so that the best option of design rainfall condition can be determined. The finalised model is then validated based on observed rainfall. Table 1 shows the scenarios tested.

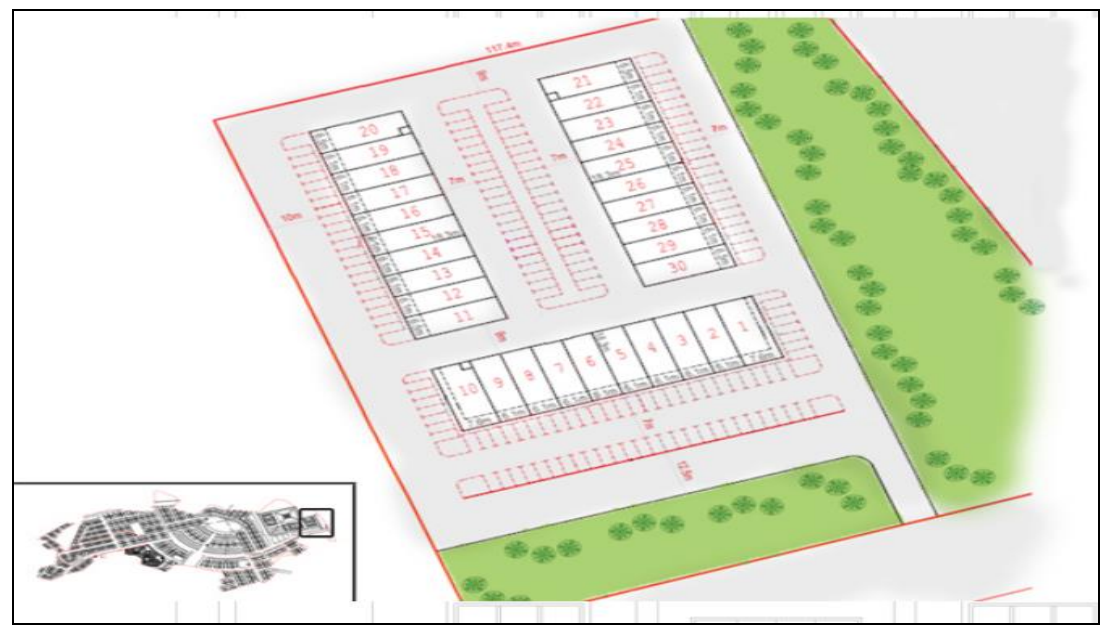

Figure 2. Detailed Layout of the Study Area

Table 1: Scenarios Involved in the Investigation

\begin{tabular}{|c|c|c|}
\hline Types of rainfall & Scenarios & Conditions \\
\hline & 1 & Investigation on the types of soil \\
\hline \multirow[t]{3}{*}{ Design Rainfall } & 2 & Investigation on the thickness of planting medium \\
\hline & 3 & Investigation on the average recurrence interval (ARI) \\
\hline & 4 & Investigation on the duration of rainfall event \\
\hline Observed Rainfall & 5 & $\begin{array}{l}\text { Investigation on the effectiveness of the green roof as an urban } \\
\text { drainage system }\end{array}$ \\
\hline
\end{tabular}

\subsection{RESULTS AND ANALYSIS}

\subsection{Investigation on Planting Medium}

From Figure 3, loam records the highest percentage of runoff reduction compared with loamy sand and sandy loam. The results from simulation using EPA SWMM 5.1 show that loam soil with a thickness of $110 \mathrm{~mm}$ can retain about $98.2 \%$ of rainfall volume. Most of the topsoil used for agriculture is loam. It is a specific textural class of soil containing equal amounts of sand, silt and clay. Sand has excellent aeration and drainage. It can be tilled easily and warms up rapidly in spring time. However, it erodes easily, and has a low capacity for holding water and nutrients. Its weakness can be rectified by silt and clay which tend to erode less quickly, and have a high capacity for holding water and nutrients. In this way, the rainfall will be retained in the silt and clay for a longer period and slowly drain out to the drainage layer at the bottom of the green roof. As some water is retained in the green roof, the amount of surface runoff is reduced and this helps to prevent flash floods. At the same time, the retained water provides a continuous supply of water to plants on the green roof. 


\subsection{Investigation on Design Rainfall}

From Figure 4, the runoff reduction percentage for each planting medium shows a decreasing trend as the average recurrence intervals (ARI) increase. The peak flows on the roof are generally much greater for high-recurrence intervals (20-, 50- or 100-year) than for low-recurrence interval floods. During an event of intense rainfall, the soil is saturated and does not have the capacity to absorb additional rainfall. Under these conditions, all of the rainfalls, whether on paved surfaces or on saturated soil, run off and form a stream flow. From the simulation of SWMM 5.1 model, loam soil with 1-year average recurrence interval records the highest percentage of runoff reduction, which is $98.22 \%$.

Meanwhile, duration of storm is another aspect investigated for its consequences in relation to runoff reduction volume. As seen in Figure 5, all of the planting mediums experimented with 1-year ARI design rainfall, have the highest percentage of runoff reduction at 15 minutes durations. The highest percentage of runoff reduction recorded is $98.22 \%$ for loam soil. Loam soil is able to retain higher surface runoff in the green roof because silt and clay have high water-holding capacity. The percentage of runoff reduction for loam shows a uniform trend as depicted in Figure 5. When rain precipitation falls on the roof sub-catchment, the high content of clay in loam soil absorbs the rainwater, causing swelling to occur. The swollen clay behaves like impermeable soil preventing water absorption from occurring for certain durations. Therefore, there is no change in runoff reduction, starting from 20 minutes' duration.

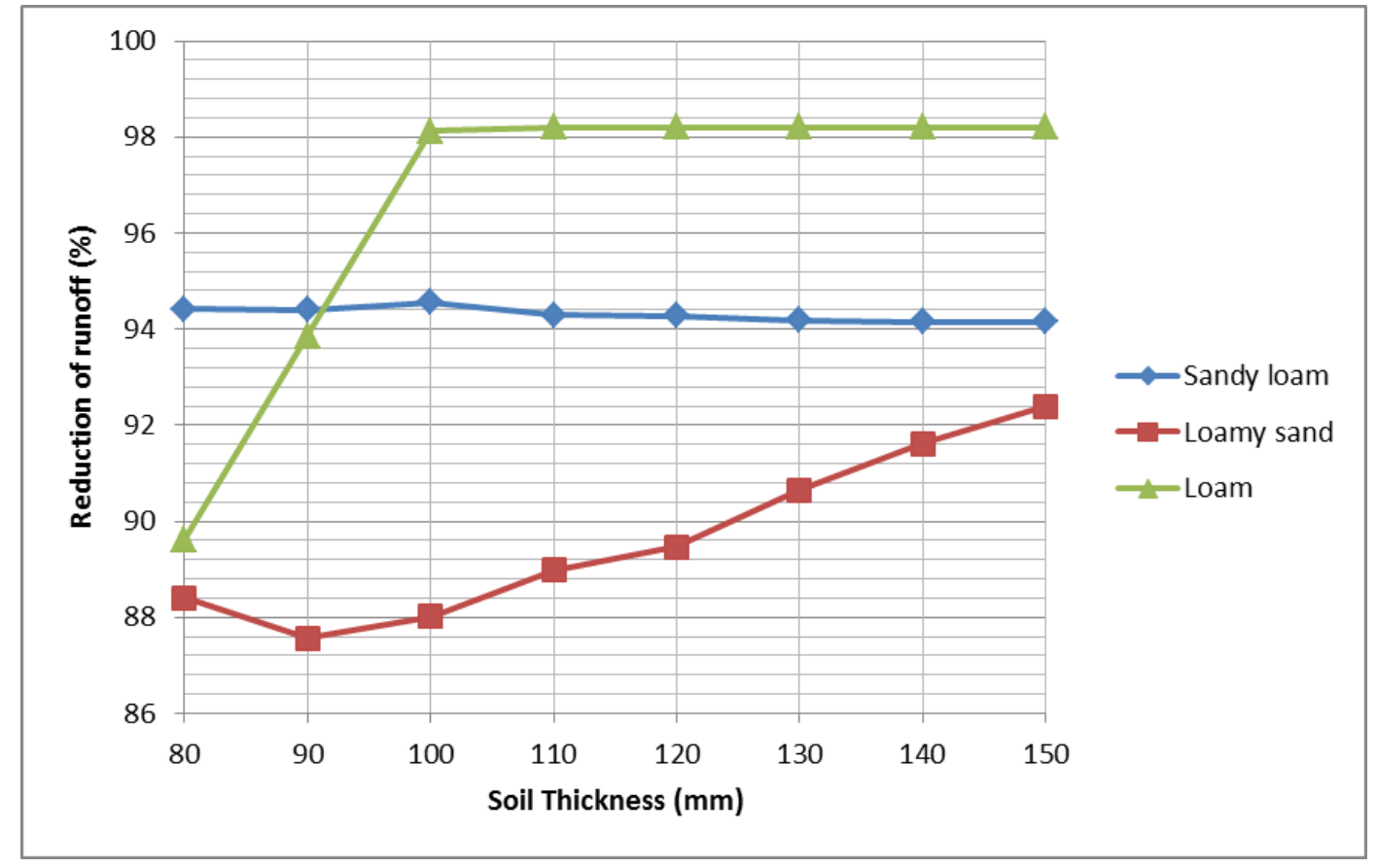

Figure 3. Performance of Planting Medium with Response to 15 minutes of 10-year ARI Design Rainfall 


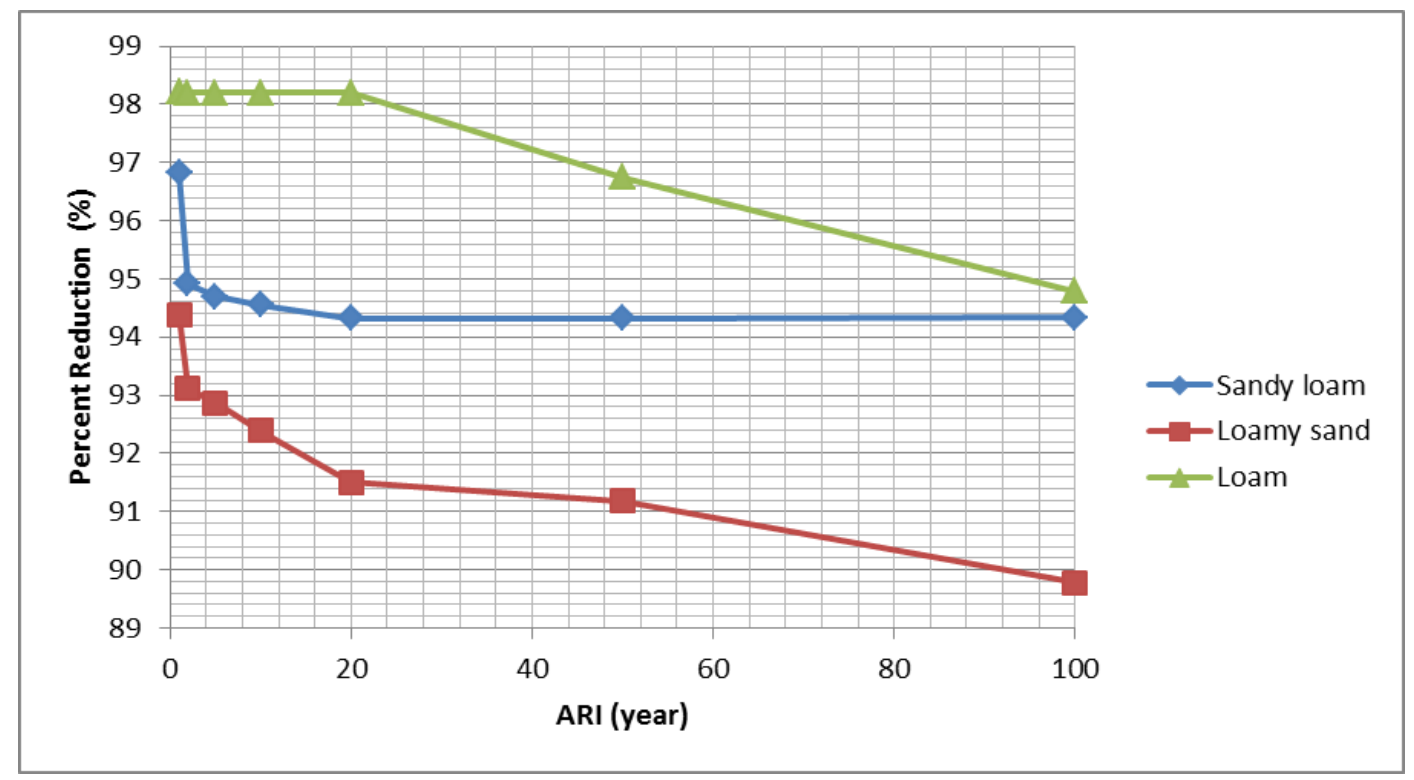

Figure 4. Effect of 15 minutes Design Rainfall according to ARI to Surface Runoff Reduction

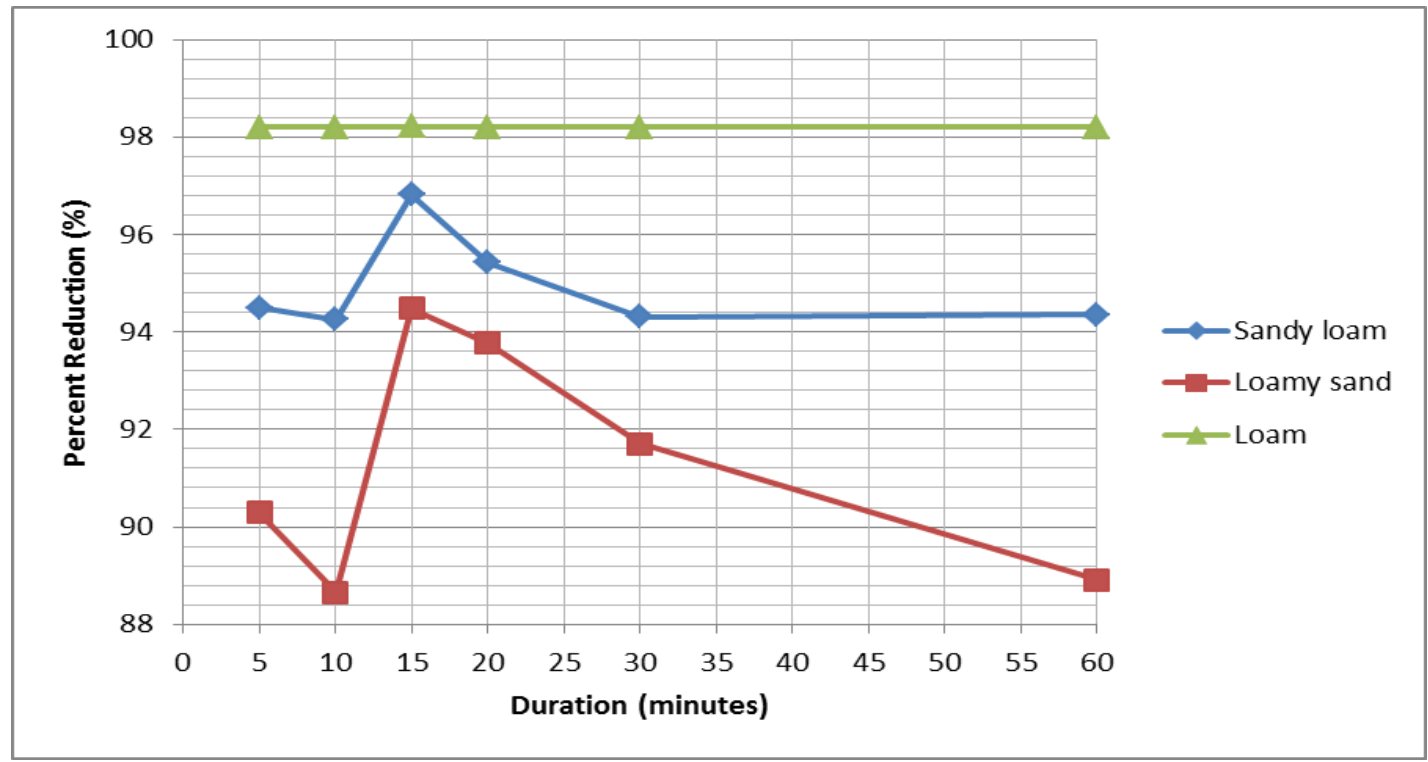

Figure 5. Effect of Duration of 1-year ARI Storm to Surface Runoff Reduction

\subsection{Investigation on Performance of Green Roof}

From all of the above investigations, the planting medium which functions most effectively in reducing surface runoff is chosen for investigation on observed rainfall. Judging from the results, loam soil achieves the optimum percentage of surface runoff reduction as compared with loamy sand and sandy loam. The highest reading recorded by loam is $98.22 \%$ with a condition of $110 \mathrm{~mm}$ thickness, 1 year average recurrence interval and 15 minutes duration.

As the investigations on design rainfall and planting medium provides the best variables in surface runoff reduction, the next step will be testing the performance of the green roof based on these best variables using real-life rainfall data obtained from Department of Irrigation and Drainage. The simulation for performance of the green roof is carried out using January and February 2014 rainfall data, as both months recorded the highest rainfall depth in 2014.

\subsection{Simulation of Green Roof}

Figures 6 and 7 below show the comparison of runoff for the roof sub-catchment with and without green roof. Runoff without green roof is shown in blue colour while runoff with green roof is indicated 
in red colour. As seen in the two figures, the green roof has greatly reduced the amount of surface runoff. From the simulation, the roof catchment integrated with green roof generates a runoff of $0.000124 \mathrm{~m}^{3} / \mathrm{s}$ in January 2014. Meanwhile, roof catchment without green roof records the highest runoff of $0.007959 \mathrm{~m}^{3} / \mathrm{s}$ for the same period of time. Both runoffs have a wide difference of up to $98.4 \%$. It is clear that the green roof has performed excellently in retaining rainwater in the planting medium and reducing much runoff of impervious surface in the month of January. Besides, the roof catchment integrated with green roof shows no fluctuation (consistent increment and decrement) in runoff for the month of January. This is due to the green roof's characteristic that it is able to retain rainwater in its medium for a period and has a controlled outflow velocity as soil has its specific hydraulic conductivity.

From Figure 7, the largest amount of the runoff is approaching zero when the roof catchment is integrated with green roof. Only one particular day of the month of February has recorded fluctuation in runoff which is on 21 February 2014. The fluctuation occurs as the rainfall is very intense in that particular period of time. Within 6 hours of continuous rainfall, the total amount of precipitation has reached to $186.5 \mathrm{~mm}$. This heavy rainfall adversely affects the efficiency of the green roof to retain runoff. The planting medium of the green roof is unable to absorb the large amount of runoff at that time. As the rain continues to fall heavily on the catchment, the runoff increases because the soil is saturated with water. In comparison, the performance of the green roof in the month of February is lower than that of the month of January. However, it is still satisfactory in that it successfully reduces the amount of runoff by up to $73 \%$.

Figure 8 shows the clear views of how the green roof has performed its function in retaining surface runoff. The runoff of the roof catchment which integrates with green roof achieves zero flow from $5 \mathrm{pm}$ to $7 \mathrm{pm}$ on day 1. This is because the 2-hour rainfall is a minor event and the green roof planting medium is able to absorb all the precipitation. In a larger storm, the green roof typically retains nearly all precipitation at the start of the event until its storage capacity is exceeded. Once the storage capacity is exceeded, runoff begins to occur; the additional precipitation is released as runoff, as demonstrated in Figure 8.

The runoff continues to increase for the next hours as the rainfall is too intense. Due to the large volume of rainwater, the planting medium is unable to absorb all the runoff in quick successions. The high velocity of runoff flow on the green roof surface reduces the absorption rate. At this point of time, the soil composition is partially saturated with water. The runoff keeps increasing as the heavy rainfall continues until $11 \mathrm{pm}$ on 1 January 2014 . As a result, the runoff increases up to $0.000124 \mathrm{~m}^{3} / \mathrm{s}$, which is the highest runoff for the month of January. The fluctuation on the amount of runoff is caused by the saturation of soil media. As the volume of void in the planting medium decreases, the amount of precipitation retained in it also decreases, and hence the runoff is increased.

Between $11 \mathrm{pm}$ to $6 \mathrm{am}$ on day 2 , the runoff volume remains unchanged. At this stage, the clay composition starts to manifest its characteristic; it swells after absorbing the precipitation. This swelling condition stops the absorption of runoff for the period. Since the amount of rainfall is almost similar in the early hours of day 2 and it only rains lightly, the runoff volume remains the same. Meanwhile, even though there is no precipitation from $6 \mathrm{am}$ to $8 \mathrm{am}$, the runoff remains the same as previous hours. This is because the water from the saturated soil begins to flow out to the drainage layer. The soil releases the water in a consistent rate.

The retained water continuously drains out for the next two hours. Therefore, the runoff is lower in these two hours compared with the previous hours. Although there is low precipitation from 9am to $10 \mathrm{am}$, the retained water in the planting medium decreases. The precipitation is again absorbed by the planting medium and filled void in it. By the way, the volume of water drained from the soil media is comparatively lower. This leads to lower runoff as observed in Figure 8. From 11am to 7pm, the runoff again decreases gradually. The difference, compared with the previous two hours, is that there is no precipitation during this period. As explained before, the water-saturated soil slowly releases water out 
of the planting medium. This runoff volume decreases continuously until all the water drains out from the soil media.

Runoff passing through the green roof is delayed from the start of the storm by a period which corresponds to that of filling the media storage capacity. From Figure 8, the time lag is about 2 hours. The runoff flow is delayed as precipitation is intercepted by vegetation canopy; the rainwater then flows down along the stems; it passes through root zone and the media before it reaches the drainage system. This time lapse for flowing through the green roof system is significantly influenced by the size of the roof, vegetation cover, path of flow, hydraulic conductivity of the media, and the drainage layer. Once precipitation reaches the drainage layer, the water drains to the roof gutter.

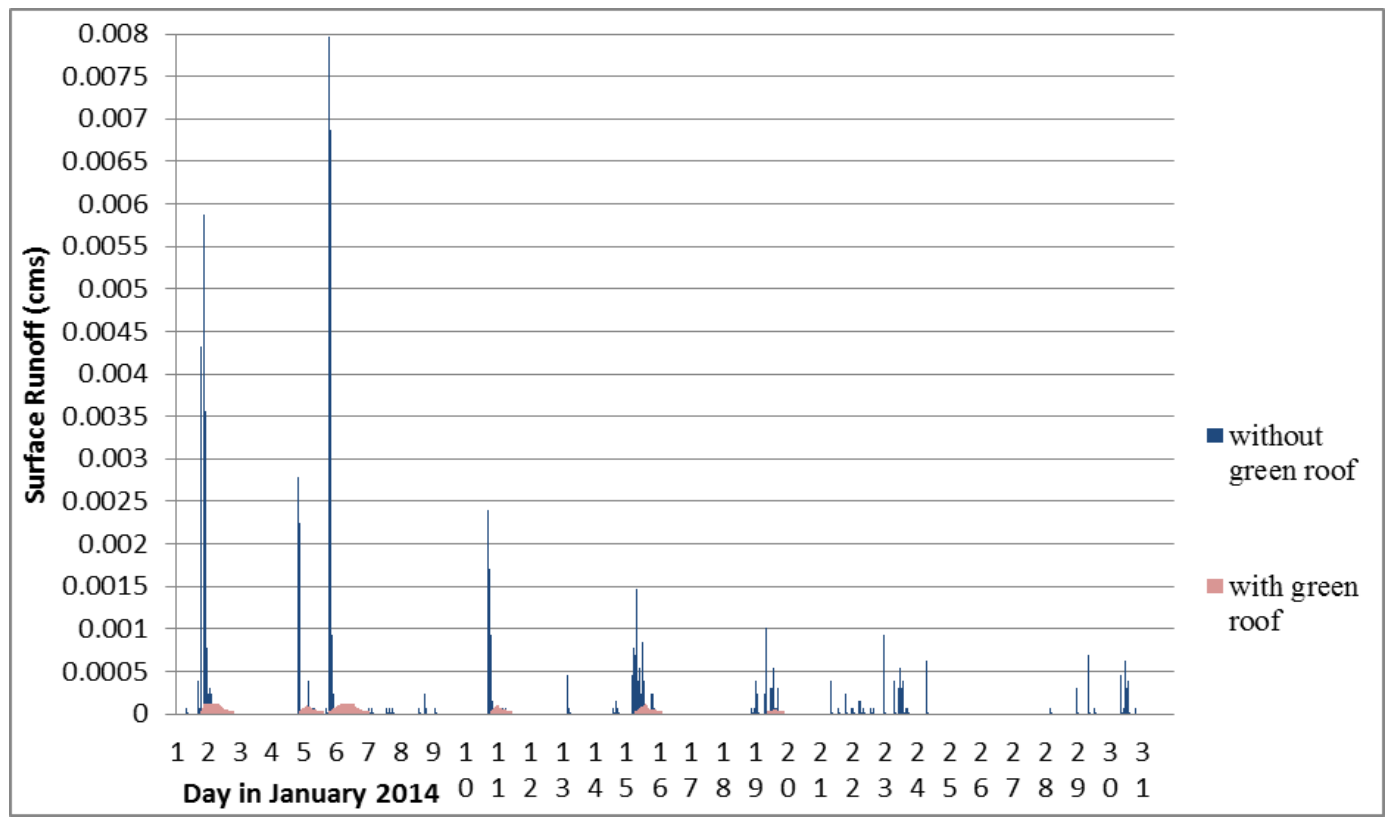

Figure 6. Computed Runoff in January 2014 


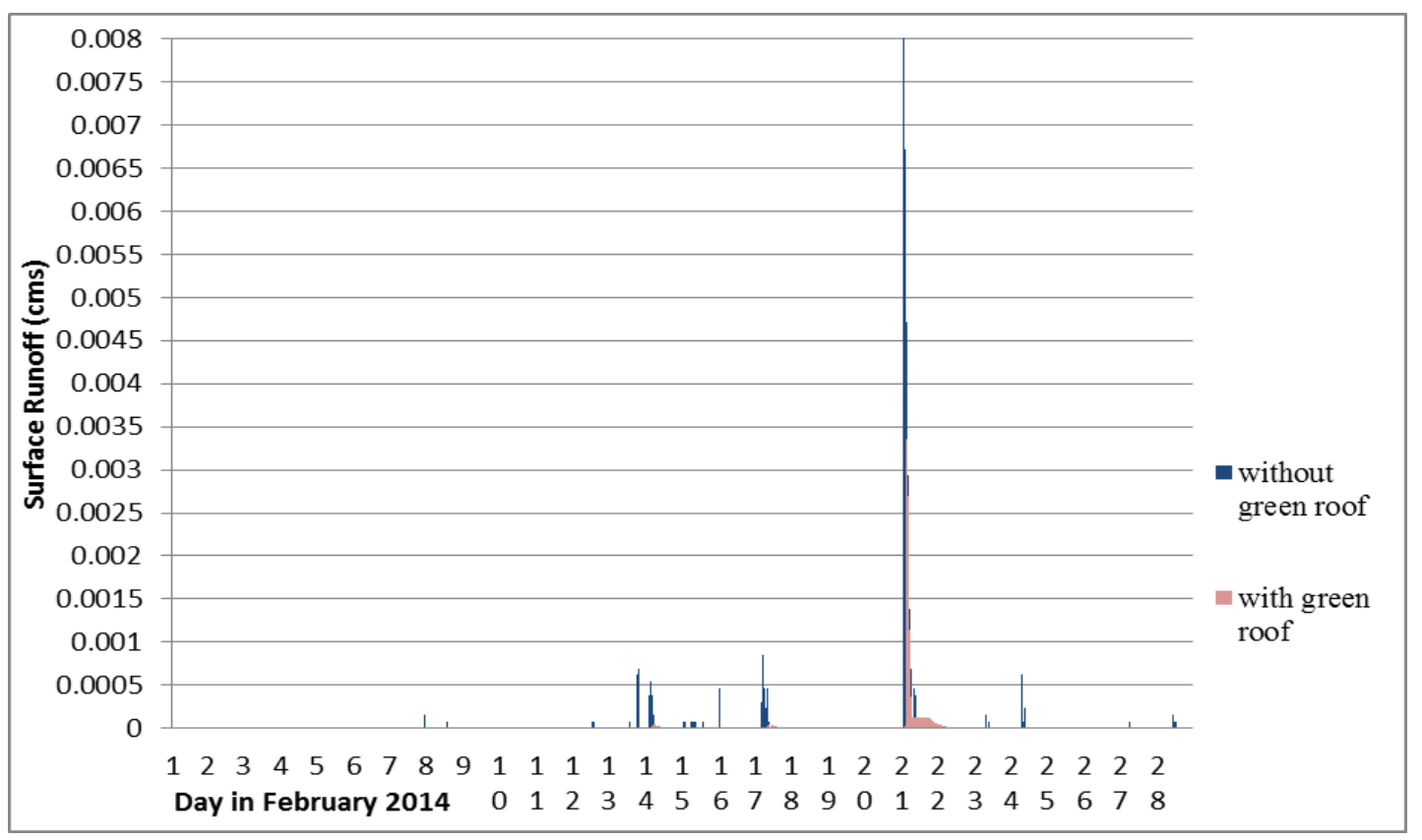

Figure 7. Computed Runoff in February 2014

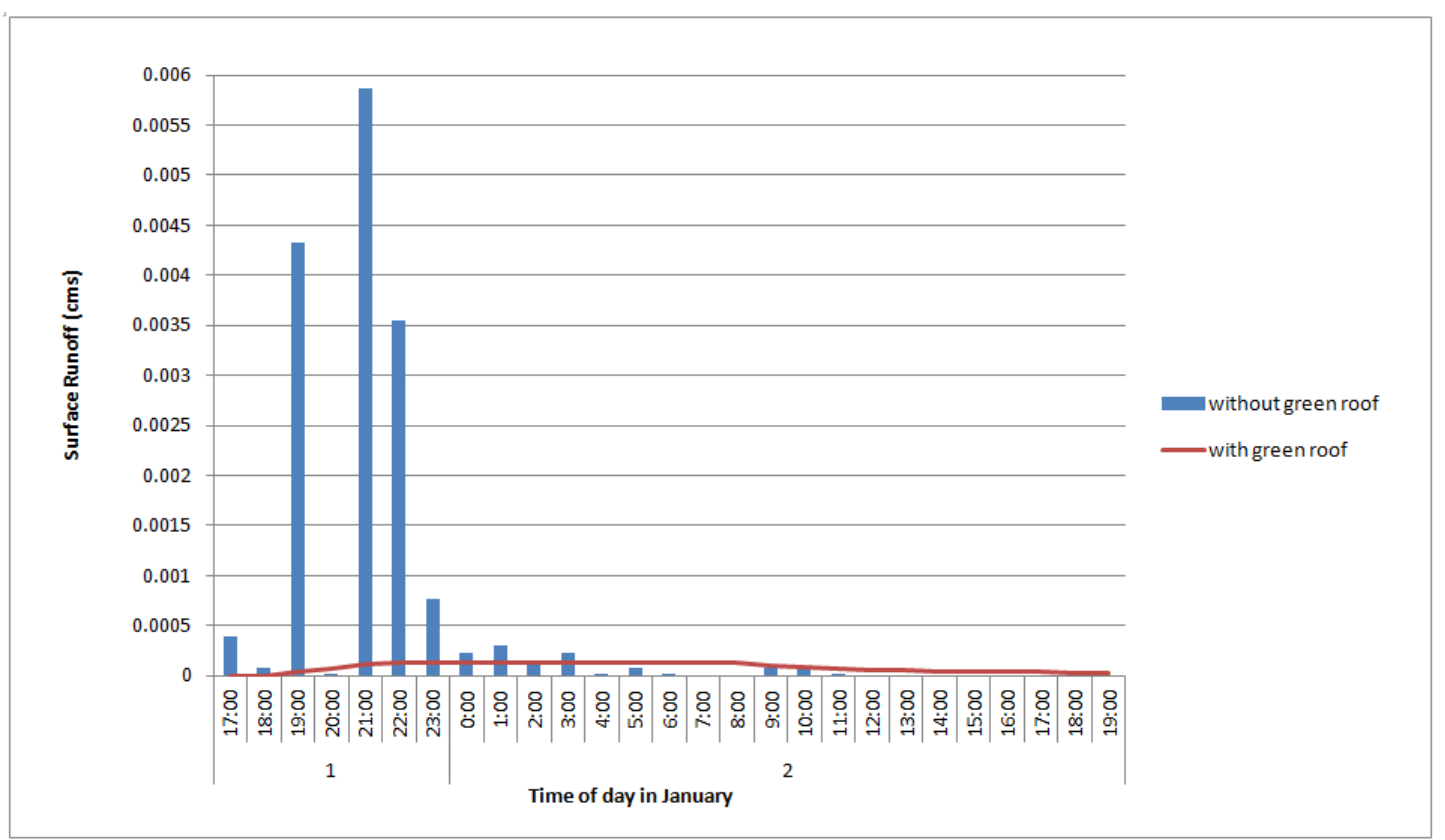

Figure 8. Green Roof Peak Outflow Rate Reduction on $1^{\text {st }}$ and $2^{\text {nd }}$ January 2014.

\subsection{Summary}

Although the green roof runoff performance depends on rainfall patterns and intervals between storms, peak flow attenuation is demonstrated in most events of storms. Short period of intense rainfall, such as that of 21 February 2014, takes a shorter time to reach peak runoff on the green roof, but still records a reduced runoff volume. It causes a lower percentage of runoff-retained in the month of February compared with that of the month of January as seen in Table 2. This difference is also attributed by another factor: most days of the month of February have either zero rainfall or very low rainfall. The intense rainfall on 21 February 2014 accounts for about $76 \%$ of the total amount of rainfall for the month. Hence, the retained percentage recorded is slightly lower in comparison, but the green roof is still able to retain $73.5 \%$ of the total rainfall. 
Table 2: Hydrologic Performance of Green Roof

\begin{tabular}{ccccccc}
\hline Month & $\begin{array}{c}\text { Total } \\
\text { Rainfall } \\
\left(\mathrm{m}^{3}\right)\end{array}$ & $\begin{array}{c}\text { Total Rainfall } \\
\text { Retained by } \\
\text { Green Roof }\left(\mathrm{m}^{3}\right)\end{array}$ & $\begin{array}{c}\text { Percent } \\
\text { Retained } \\
(\%)\end{array}$ & $\begin{array}{c}\text { Peak Flow } \\
\text { without Green } \\
\text { Roof }\left(\mathrm{m}^{3} / \mathrm{s}\right)\end{array}$ & $\begin{array}{c}\text { Peak Flow with } \\
\text { Green Roof } \\
\left(\mathrm{m}^{3} / \mathrm{s}\right)\end{array}$ & $\begin{array}{c}\text { Percent } \\
\text { Reduction } \\
(\%)\end{array}$ \\
\hline $\begin{array}{c}\text { January } \\
2014\end{array}$ & 57.9 & 50.3 & 86.9 & 0.007959 & 0.000124 & 98.4 \\
$\begin{array}{c}\text { February } \\
2014\end{array}$ & 34.3 & 25.2 & 73.5 & 0.012441 & 0.000124 & 99 \\
\hline
\end{tabular}

In the month of January, the green roof successfully retains about $86.9 \%$ of the total rainfall. This scenario occurs because there are some longer rainfall events in that month, such as 1 January and 15 January 2014. The long rainfall events take longer times to peak and this allows the absorption of precipitation for those instances. The hydrologic performance statistics as demonstrated in Table 2 prove that green roof has a good capability of retaining the precipitation even during monsoon seasons. The month of January has very frequent rainfalls but they are mostly of low or moderate intensity. This condition does not have much negative impact on the performance of the green roof as bio-retention system. The only problem arises is insufficient length of time for the planting media to dry out, as most rainfall events occur one after another. Only a small percentage of retained water turns into runoff when the amount of precipitation exceeds the storage capacity of planting medium.

\subsection{CONCLUSION}

In conclusion, the computer-aided stormwater model (EPA SWMM 5.1) which incorporates green roof has been developed to determine the runoff for a post development area. From the model simulation, green roof with loam soil of $110 \mathrm{~mm}$ thickness proves to be the best medium for the bio-retention system in comparison with other planting mediums. Overall, the green roof evaluated effectively retains $73.5 \%$ and $86.9 \%$ of runoff in January and February of 2014 respectively. The green roof reduces the normal peak flow of $0.007959 \mathrm{~m}^{3} / \mathrm{s}$ to a runoff rate of $0.000124 \mathrm{~m}^{3} / \mathrm{s}$ for the month of January. Additionally, the green roof delays the start of runoff for about 2 hours and delays the peak runoff response for about 1 hour for the both months. The green roof is also effective in retaining $100 \%$ of several storms of less than $10 \mathrm{~mm}$. The high percentage of water retained by the green roof for the both months demonstrates that the proposed extensive green roof for the study area functions as an excellent BMP for water detention. The results of this research also show that green roof could be an effective device for controlling the peak flows of runoffs. Peak flow reduction of stormwater runoff is the main objective of MSMA. The results of this research are in line with those of other researches performed throughout the world pertaining to green roof hydrologic characteristics.

This research project may have some limitations when it comes to drought seasons. Green roof should be tested in other weather variability so that further design specifications of plant mixtures, media depths, and potential irrigation requirements can be determined. The weather conditions should also include long-term studies; it is very likely that in dry years, the green roof runoff would be far less than that of wet years. Additional studies should be conducted to identify more plant species suitable for green roofs, especially the varieties that are drought resistant and require minimal nutrient supplements. Meanwhile, the effects of green roof runoff discharged into receiving watercourses have not been explored; also, the authors of this research are uncertain concerning the need of additional treatment for green roof discharge and this issue has not been investigated. In rural areas, green roof runoff treatment may be as simple as directing the downspouts to grass swales or collecting green roof runoff in rain barrels for irrigation purposes. However, this may not be practical in urban areas where there is limited space for stormwater controls. Further studies should be carried out to improve the runoff quality. It is not recommended to have the green roof runoff directly discharged into receiving watercourses. 


\section{ACKNOWLEDGMENT}

The authors wish to thank the Faculty of Engineering, Universiti Malaysia Sarawak for the opportunity to undertake this project, and the Department of Irrigation and Drainage of Sarawak for the support to complete the research.

\section{REFERENCES}

[1] M. O’Driscoll, S. Clinton, A. Jefferson, A. Manda, and S. McMillan, “Urbanization Effects on Watershed Hydrology and In-Stream Processes in the Southern United States, ” 2, 2011, 605-648; doi: 10.3390/w2030605

[2] M. Annika, “Green Roof in Seattle- A Survey of Vegetated Roof \& Rooftop Gardens”. Department of Planning and Development, City of Seattle, 2010.

[3] V. Vandermeulen, A. Verspecht, B. Vermeire, G. Van Huylenbroeck, and X. Gellynck, "The use of economic valuation to create public support for green infrastructure investments in urban area," Landscape and Urban Planning 103(2), 2011, 198-206.

[4] Volder, Astrid, and Dvorak, "Event size, substrate water content and vegetation affect storm water retention efficiency of an un-irrigated extensive green roof system in Central Texas," Sustainable Cities and Society 10, 2014, 59-64.

[5] G. W. Christopher, and W. W. Wendy, "Green Roof Specifications and Standards," 56(8). USA, 2003.

[6] J. Jacklyn, and N. John, "Building Green: A Guide to Using Plants on Roofs, Walls and Pavements". London, England: Greater London Authority, 2004.

[7] W. Allan, "The Filter, Drain, and Water Holding Components of Green Roof Design". America: Colbond, Inc, 2005.

[8] Center for Neighbourhood Technology. "The Value of Green Infrastructure," A Guide to Recognising Its Economic, Environmental and Social Benefits. North Avenue, Chicago, 2010.

[9] B. Hunt, G. Jennings, and A. Moran, "A North Carolina Field Study to Evaluate Green Roof Runoff Quantity, Runoff Quality, and Plant Growth". North Carolina State University, Department of Biological and Agricultural Engineering, 2004. 